\title{
A stimulatory effect of the fluid from preimplantation rabbit blastocysts upon luteinization of monkey granulosa cell cultures
}

\author{
Cornelia P. Channing, Sarah L. Stone, Carol N. Sakai, France Haour* \\ and Brij B. Saxena† \\ Department of Physiology, University of Maryland School of Medicine, $660 \mathrm{~W}$. Redwood Street, \\ Baltimore, Maryland 21201, U.S.A.; \\ *Inserum, U34 Hospital Debrousse, 29 Chemin Soeur Bouvier, 69322 Lyon, France; and \\ †Division of Endocrinology, Department of Medicine, Cornell University Medical College,
} New York, New York 10021, U.S.A.

\begin{abstract}
Summary. Blastocyst fluid was aspirated from Day $6 \frac{1}{2}-7$ rabbit blastocysts and was added to cultures of granulosa cells obtained from preovulatory follicles of untreated rhesus monkeys or from follicles of monkeys treated with PMSG. The stimulation of progesterone secretion was measured and equated with that produced by hCG. The hCG-like activity was also measured in a radioreceptor assay using ${ }^{125}$ I-labelled hCG and porcine granulosa cells.

In 8 out of 10 experiments with cultured cells from untreated monkeys, addition of $20 \%$ blastocyst fluid from Days 6-9 of culture stimulated progesterone secretion by 2to 6-fold. Similar findings were obtained in 5 experiments with cultures from PMSGtreated monkeys except that the blastocyst fluid was added from Days 0 to 6 of culture. The granulosa cells in such cultures underwent morphological luteinization. Compared to a standard of purified hCG the blastocyst fluid contained about $0.76-2.5 \mathrm{ng}$ hCGlike activity/ml which was non-dialysable. The radioreceptor assay indicated the presence of $0.5-2.5 \mathrm{ng} \mathrm{hCG}$-like material $/ \mathrm{ml}$.
\end{abstract}

\section{Introduction}

The observation of Fuchs \& Beling (1974) that blood progestagen concentrations in the pregnant rabbit are significantly higher than those in the pseudopregnant rabbit after only 5 days of gestation indicates either that the conceptus may be secreting a substance which stimulates the corpus luteum (CL) to secrete progesterone or that the blastocyst itself could be secreting the progestagen. Implantation in the rabbit occurs 7 days post coitum and so the stimulus for such secretion must come from the preimplantation blastocyst. Haour \& Saxena (1974) observed that preimplantation rabbit blastocyst fluid contained a substance(s) which could inhibit the binding of labelled hCG to membranes of bovine luteal cells, and concluded that the blastocyst could secrete an hCG-like gonadotrophin which could act locally to stimulate luteal progestagen secretion before implantation. Fujimoto, Euker, Riegel \& Dukelow (1975), using a non-specific LH antiserum, were also able to demonstrate a substance in blastocyst fluid which could inhibit binding of iodinated LH to the antiserum. However, Holt, Heise, Wilson \& Keyes (1976) and Sundaram, Connell \& Passantino (1975) were unable to detect any hCG-like activity in rabbit blastocyst fluid when using in-vitro assays with rat ovarian and Leydig cells, respectively. Because of these discrepancies we decided to assay the luteotrophic activity of fluid from rabbit preimplantation blastocysts by using cultures of monkey granulosa cells which are known to respond to small doses of gonadotrophins (Channing, 1970, 1974; Channing \& Kammerman, 1973) with an increase in progesterone secretion and morphological luteinization. Monkey granulosa cells can respond to gonadotrophins of a wide range of species including reptiles, sheep, pigs, monkeys and man (Channing, Licht, Papkoff \& Donaldson, 1974; Channing, 1974). 


\section{Materials and Methods}

\section{Collection of blastocyst fluid}

Rabbit blastocysts were obtained by two methods from 16 mature New Zealand White rabbits. Some rabbits were mated at oestrus and 6-7 days later the rabbits were killed with sodium pentobarbitone and the uteri were removed. The blastocysts were located and either flushed out or left in situ and the blastocyst fluid was aspirated by a 23 -gauge needle and $1-\mathrm{ml}$ syringe and immediately placed on ice and centrifuged at $1000 \mathrm{~g}$ to remove cells and debris. In the second method, oestrous rabbits were induced to ovulate by an intravenous injection of $100 \mu \mathrm{g}$ ovine LH (NIH-LH-S18) dissolved in $1 \mathrm{ml}$ phosphate-buffered saline. The rabbits were immediately inseminated artificially with $1 \times 10^{8}$ spermatozoa collected from males of proven fertility. On the 7 th day after the LH injection the females were tranquillized with an intravenous injection of $3 \mathrm{mg}$ acepromazine maleate (Ayerst, New York, U.S.A.) and anaesthetized with $75 \mathrm{mg}$ sodium pentobarbitone (Abbott, North Chicago, Illinois, U.S.A.). The uterine horns were exposed by laparotomy and blastocyst fluid was harvested from the expanded blastocysts by aspiration through the uterine wall with a 23 -gauge needle attached to a $1-\mathrm{ml}$ syringe. The blastocyst fluid was immediately transferred to sterile tubes on ice and centrifuged to remove cells and debris. All the blastocyst fluid samples were frozen at $-20^{\circ} \mathrm{C}$ until used in monkey granulosa cell cultures or in the radioreceptor assay.

\section{Monkey granulosa cells}

Collection. Eleven (11) rhesus monkeys were used as a source of granulosa cells for the assay of hCG-like activity. The housing and care was as described previously (Channing, 1970). The granulosa cells were from preovulatory follicles of untreated monkeys and from follicles of monkeys treated with PMSG. The 8 untreated monkeys were observed for two consecutive menstrual cycles and, during the third menstrual cycle, they were bled daily from Day 5 until Days 9 to 12 (Day $1=$ first day of menstruation). A rapid radioimmunoassay of oestrogen was carried out on each serum sample as originally described by Hotchkiss, Atkinson \& Knobil (1971) and modified and validated by Channing \& Coudert (1976). On the day of the oestrogen 'surge' ( $>200 \mathrm{pg}$ oestrogen $/ \mathrm{ml}$ serum) the monkey was subjected to laparotomy and the granulosa cells were harvested from the largest follicle present (Channing \& Ledwitz-Rigby, 1975). Only follicles 4 to $11 \mathrm{~mm}$ in diameter were used. In 4 out of 8 animals examined intact oocytes were recovered which were immature and contained a germinal vesicle or had a polar body.

The 3 treated monkeys were injected subcutaneously with PMSG as outlined previously (Channing, 1974; Channing \& Ledwitz-Rigby, 1975): 1000 i.u. were given on Days 1 and 2, 500 i.u. on Days 3, 4 and 5, and 200 i.u. on Days 7-9. The monkeys were bilaterally ovariectomized on Day 10 of the treatment schedule. At this time, the ovaries were enlarged and contained numerous 3-10 mm follicles. Blood oestrogen was measured by radioimmunoassay (Channing \& Coudert, 1976) daily during the treatment period. Granulosa cells were aspirated from the follicles and cultured. Such granulosa cells secrete low basal levels of progesterone and are highly responsive to exogenous gonadotrophin (hCG, LH and FSH) added from the start of culture (Channing \& Ledwitz-Rigby, 1975). The PMSG treatment was used because large numbers of granulosa cells could be harvested from each monkey.

Culture. Aliquots of $0.1-0.5 \times 10^{6}$ granulosa cells were cultured in Microtest Plates (Falcon Plastics, Oxnard, California, U.S.A.) in a volume of $0.2 \mathrm{ml}$ medium 199 with $25 \mathrm{~mm}$-Hepes buffer, $50 \mu \mathrm{g} \mathrm{Gentamicin} / \mathrm{ml}$ and $15 \%(\mathrm{v} / \mathrm{v})$ serum from a fasting male monkey. This serum contained $<1 \mathrm{ng}$ hCG-like material/ml (measured by radioreceptor assay: Channing, 1974), $<60 \mathrm{pg}$ oestrogen/ml and 1-2 ng progesterone/ml (measured by radioimmunoassays: Channing \& Coudert, 1975). This culture medium was designated as Medium W. The cultures were maintained at $37^{\circ} \mathrm{C}$ in a humidified atmosphere of $5 \% \mathrm{CO}_{2}$ in air. The medium was changed every 2 days and frozen for later progesterone analysis by radioimmunoassay. At the end of the culture period, the cells were fixed in $10 \%$ aqueous formalin and stained with haematoxylin and eosin or oil red $\mathrm{O}$ and haematoxylin. Blastocyst fluid (usually $20 \%$ by volume in culture Medium W) or an hCG standard $(1,10,100 \mathrm{ng} / \mathrm{ml}$ culture medium) was added at the beginning of culture (PMSG-treated follicles) or at Day 5 or 6 of culture (untreated 
follicles) and at each medium change until the end of the culture period (usually Day 12). The standard of hCG (12 000-14 000 i.u./mg) was kindly donated by Dr Robert Canfield, Columbia University, New York.

\section{Progesterone assay}

Progesterone in the spent culture medium was measured, without prior extraction, by using an antiserum against 11-hydroxyprogesterone conjugated to BSA (No. 325) and the radioimmunoassay previously described and validated for this laboratory (Channing \& Ledwitz-Rigby, 1975; Channing, Tsai \& Sachs, 1976). To use progesterone secretion rate as an approximate quantitative assay of hCGlike activity, the progesterone secretion rate was first normalized to give a per cell per day value before being expressed as a percentage of the control (secretion rate observed in the absence of hormones) value so that results of experiments with different control secretion rates could be compared.

\section{Vacuum dialysis}

A pool of blastocyst fluid obtained from 3 rabbits was placed in a vacuum dialysis apparatus and dialysed overnight against $50 \mathrm{ml}$ Eagle's medium. The blastocyst fluid was then reconstituted to its original volume in Medium W and passed through a 0.22 millipore filter. Aliquots of $20 \mu \mathrm{l}$ reconstituted dialysate were added to $400 \mu \mathrm{l}$ culture medium and the mixture ( $5 \%$ blastocyst fluid) was added on Days 6 and 8 of culture to 3 replicate cultures of granulosa cells obtained from a preovulatory monkey follicle.

\section{Radioreceptor assay}

The hCG-like material present in the rabbit blastocyst fluid was quantitated by a radioreceptor assay which employed (per tube) $5 \mathrm{ng}$ (in $100 \mu \mathrm{l}$ ) ${ }^{125} \mathrm{I}$-labelled hCG $(20-30 \mu \mathrm{Ci} / \mu \mathrm{g})$, porcine granulosa cell suspension in $100 \mu \mathrm{l} 100 \mathrm{~mm}$-Tris, $\mathrm{pH} 6.5$, and $100 \mu \mathrm{l}$ test solution or standard hCG in $100 \mu \mathrm{l}$ $100 \mathrm{~mm}$-Tris, $\mathrm{pH} 6.5$, plus $0.1 \% \mathrm{BSA}$. The reaction mixture (total volume $0.3 \mathrm{ml}$ ) was mixed by shaking for $1 \mathrm{~h}$ at $37^{\circ} \mathrm{C}$ followed by centrifugation, 3 washes in $3 \mathrm{ml} 100 \mathrm{~mm}$-Tris containing $0 \cdot 1 \%$ purified pigskin gelatin (Eastman, New York, U.S.A.), pH 6.5, and counting of the cell pellet in an autogamma counter.

Details of the preparation of the porcine granulosa cells and the radioreceptor assay have been published elsewhere (Sakai, Engel \& Channing, 1977). Non-specific binding was determined by examining the amount of ${ }^{125} \mathrm{I}$-labelled hCG bound in the presence of excess unlabelled hCG $(1 \mu \mathrm{g})$ and was usually $<10 \%$ of total binding. Binding to the glass tubes used in the assay represented $<1 \%$ of total binding and was subtracted from each value. The coefficient of variation of three hCG standard curves was $7.8 \%$ on a log-logit slope comparison. The lowest detectable level of hCG-like material in this assay was $0.4 \mathrm{ng} / \mathrm{ml}$. The 'control' solution was $100 \mu 1100 \mathrm{~mm}-\mathrm{Tr}_{\mathrm{r}}$ is, $\mathrm{pH} 6.5$, plus $0.1 \% \mathrm{BSA}$ and the binding in this solution did not differ from that with a solution containing $0.9 \%$ $\mathrm{NaCl}, 100 \mathrm{~mm}$-Tris and $0 \cdot 1 \% \mathrm{BSA}(\mathrm{pH} 7)$.

\section{Results}

Blastocyst fiuid samples obtained from LH-treated artificially inseminated rabbits exerted a small but significant 2- to 6-fold stimulation in progesterone secretion in cultures of granulosa cells from preovulatory or PMSG-treated monkeys (Table 1). Rabbit serum obtained from 3 rabbits at the same time as the blastocyst fluid had no detectable stimulatory action upon progesterone secretion (Table 1). There was considerable variation in the ability of blastocyst fluid obtained from different rabbits to stimulate progesterone secretion. For example, two samples of blastocyst fluid (from different rabbits and not shown in Table 1) exerted a $3296 \%$ and $2090 \%$ stimulation in replicate cultures with one batch of granulosa cells. In another culture experiment two additional samples of blastocyst fluid exerted a $1190 \%$ and $<300 \%$ stimulation over a 3-day period. Variability in control progesterone secretion rate between replicate cultures in the same experiment was only $20 \%$. It was possible to make approximate potency estimates of the hCG-like activity in different batches of blastocyst fluid: by using $\mathbf{1 0}$ cultures from untreated, preovulatory monkeys as ran lissayesystem; the approximate 1:32:31AM 
maximal potency, expressed as ng native $\mathrm{hCG} / \mathrm{ml}$, was estimated as $0.6,0.6$ and 2.5 for blastocyst fluid from mated untreated rabbits, and 1.0, 0.7, 0.8, 0.6, 0.8, 0.5 and 0.5 for blastocyst fluid harvested from LH-treated artificially inseminated rabbits. The mean value for these 10 estimates was $0.86 \mathrm{ng}$ $\mathrm{hCG} / \mathrm{ml}$. When 5 cultures of cells obtained from PMSG-treated monkeys were used for the assay system the potencies were $0.12,0.12,0.5,10$ and $2.5($ mean $=2.6) \mathrm{ng} \mathrm{hCG} / \mathrm{ml}$.

Table 1. Effect of rabbit blastocyst fluid (BF) and hCG upon progesterone secretion by cultures of monkey granulosa cells from (a) preovulatory follicles of untreated monkeys and (b) follicles of PMSG-treated monkeys

\begin{tabular}{|c|c|c|c|c|c|c|c|}
\hline & \multirow{3}{*}{$\begin{array}{l}\text { Days in } \\
\text { culture }\end{array}$} & \multirow{3}{*}{$\begin{array}{l}\text { Addition to } \\
\text { culture }\end{array}$} & \multicolumn{5}{|c|}{ Progesterone secretion rate } \\
\hline & & & \multirow{2}{*}{$\begin{array}{c}\begin{array}{c}\text { Control } \\
(\mathrm{pg} / \text { cell/day })\end{array} \\
\text { Mean } \pm \text { s.e.m. }\end{array}$} & \multirow[b]{2}{*}{$n$} & \multicolumn{3}{|c|}{$\begin{array}{l}\text { With blastocyst fluid or hCG } \\
\text { ( } \% \text { of control })\end{array}$} \\
\hline & & & & & Mean \pm s.e.m. & $n$ & Significance \\
\hline \multirow[t]{9}{*}{ (a) } & 6 & $20 \% \mathrm{BF}$ & $24 \pm 11$ & 6 & $267 \pm 67$ & 9 & $P<0.01$ \\
\hline & 8 & $20 \% \mathrm{BF}$ & $22 \pm 13$ & 6 & $308 \pm 63$ & 8 & $P<0.01$ \\
\hline & 10 & $20 \% \mathrm{BF}$ & $13 \pm 11$ & 6 & $198 \pm 29$ & 6 & $P<0.01$ \\
\hline & 6 & $10 \mathrm{ng} h \mathrm{CG}$ & $24 \pm 11$ & 6 & $1057 \pm 501$ & 4 & - \\
\hline & 8 & $10 \mathrm{ng}$ hCG & $22 \pm 13$ & 6 & $3512 \pm 1808$ & 4 & - \\
\hline & 10 & $10 \mathrm{ng} \mathrm{hCG}$ & $13 \pm 11$ & 6 & $19673 \pm 1300$ & 3 & - \\
\hline & 6 & $20 \%$ rabbit serum & $57 \pm 11$ & 4 & $47 \overline{(38}, 55)$ & 2 & - \\
\hline & 8 & $20 \%$ rabbit serum & $62 \pm 6.6$ & 4 & $34(28,40)$ & 2 & - \\
\hline & 10 & $20 \%$ rabbit serum & $57 \pm 6 \cdot 1$ & 4 & $26(20,32)$ & 2 & - \\
\hline \multirow[t]{12}{*}{ (b) } & 2 & $5 \% \mathrm{BF}$ & $1 \cdot 27(1 \cdot 24,1 \cdot 30)$ & 2 & $117(114,119)$ & 2 & $\ldots$ \\
\hline & 4 & $5 \% \mathrm{BF}$ & $0.84(0.98,0.70)$ & 2 & $130(102,158)$ & 2 & - \\
\hline & 6 & $5 \% \mathrm{BF}$ & $0.35(0.33,0.36)$ & 2 & $96(80,111)$ & 2 & - \\
\hline & 2 & $20 \%$ BF & $0.81 \pm 0.27$ & 8 & $556 \pm 132$ & 8 & $P<0.01$ \\
\hline & 4 & $20 \% \mathrm{BF}$ & $0.59 \pm 0.15$ & 8 & $1587 \pm 348$ & 8 & $P<0.01$ \\
\hline & 6 & $20 \% \mathrm{BF}$ & $0.40 \pm 0.003$ & 8 & $1239 \pm 351$ & 8 & $P<0.01$ \\
\hline & 2 & $1 \mathrm{ng} \mathrm{hCG}$ & $1 \cdot 27(1 \cdot 24,1 \cdot 3)$ & 2 & $1116(1013,1219)$ & 2 & - \\
\hline & 4 & $1 \mathrm{ng} \mathrm{hCG}$ & $0.84(0.98,0.70)$ & 2 & $739(641,836)$ & 2 & - \\
\hline & 6 & $1 \mathrm{ng} \mathrm{hCG}$ & $0.35(0.33,0.36)$ & 2 & $510(451,568)$ & 2 & - \\
\hline & 2 & $10 \mathrm{ng}$ hCG & $1.27(1.24,1 \cdot 30)$ & 2 & $2309(2283,2334)$ & 2 & $\ldots$ \\
\hline & 4 & $10 \mathrm{ng}$ hCG & $0.84(0.98,0.70)$ & 2 & $4262(4120,4401)$ & 2 & - \\
\hline & 6 & $10 \mathrm{ng} \mathrm{hCG}$ & $0.35(0.33,0.36)$ & 2 & $11210(10120,12300)$ & 2 & - \\
\hline
\end{tabular}

The hCG or blastocyst fluid was added at Days 5,6 and 8 of culture for (a) and Days 0, 2, 4 and 6 of culture for (b).

Blastocyst fluid which had been vacuum dialysed overnight in Eagle's medium retained its ability to stimulate progesterone secretion: a $5 \%$ solution brought about a $449 \pm 66 \%(n=3)$ stimulation over 3 days of culture. In the same experiment $1.0 \mathrm{ng} \mathrm{hCG}$ exerted a $331 \%$ stimulation of progesterone secretion.

The blastocyst fluid also stimulated morphological luteinization of the granulosa cells (Pl. 1, Figs 1, 2 and 3). The effect was most evident after 4 days of exposure of the cells to the fluid. At a concentration of $20 \%$, blastocyst fluid increased the accumulation of small dense granules and lipid droplets in granulosa cells examined by phase-contrast microscopy and after oil red $\mathbf{O}$ staining. Addition of the $0.9 \% \mathrm{NaCl}$ or phosphate-buffered saline plus $0.1 \% \mathrm{BSA}$ (pH 7.4) 'control' solution did not cause these morphological changes.

The results of the radioreceptor assay of the blastocyst fluid from individual rabbits are shown in Table 2. The hCG-like activity was often barely detectable and close to the limit of sensitivity of the assay. The range of potency estimates from the radioreceptor assay approximated that obtained from the monkey granulosa cell culture assay. 

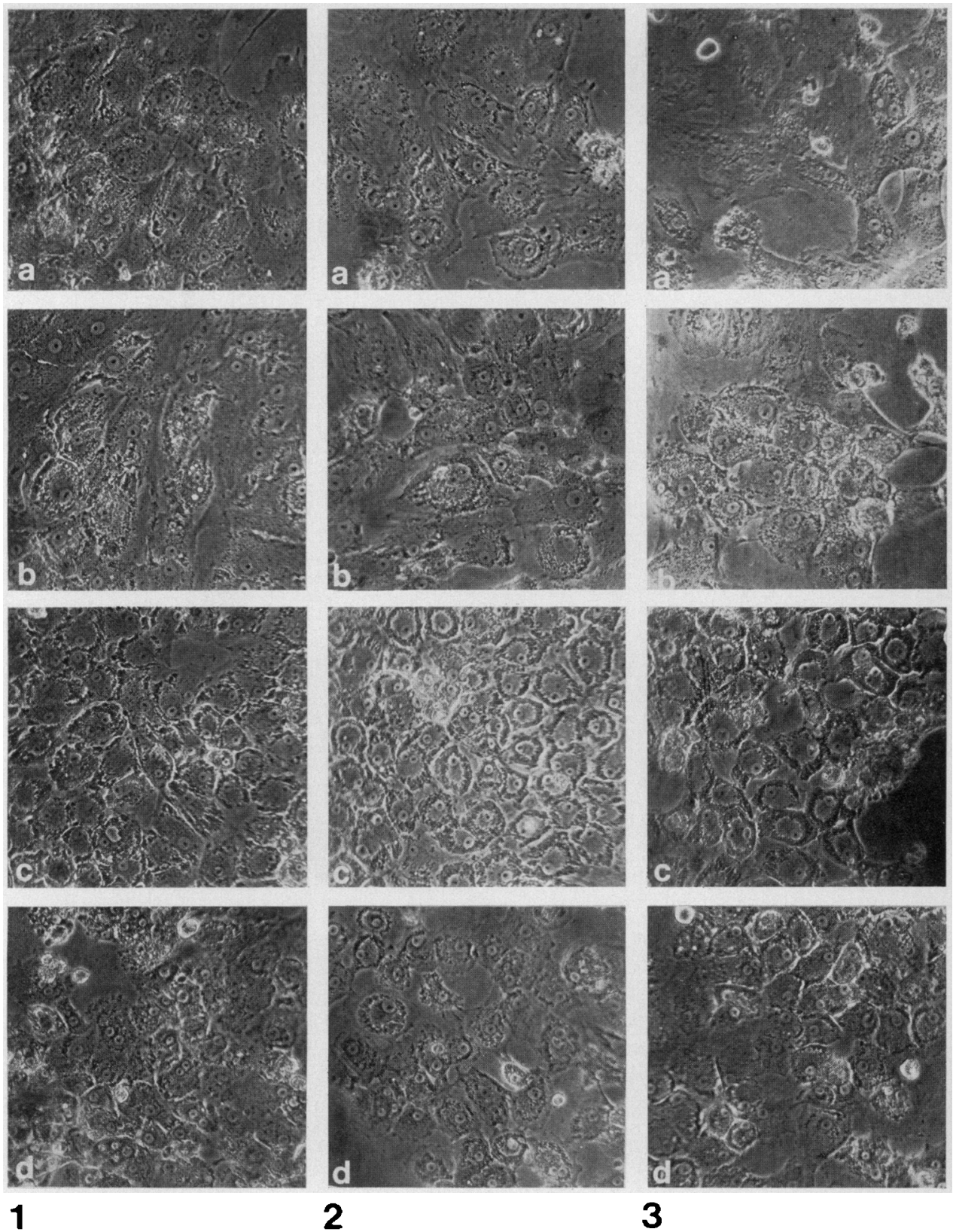

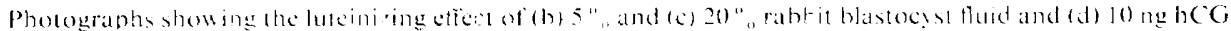

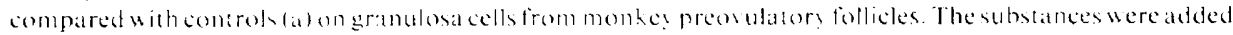
afler 7 das of culture $\times 350$

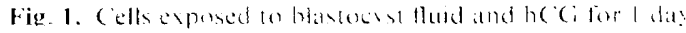

Fig. 2. Collsexponed bir z das.

Hig. 3. Collowponed tort dis 
Table 2. Estimation of hCG-like activity in rabbit blastocyst fluid by a radioreceptor assay

\begin{tabular}{|c|c|c|c|c|c|c|c|}
\hline $\begin{array}{l}\text { Rabbit providing } \\
\text { fluid ( } 100 \mu 1 / \text { assay) }\end{array}$ & 1 & 2 & 3 & 4 & 5 & 6 & 7 \\
\hline $\begin{array}{l}\text { hCG-like activity } \\
\text { (ng/ml) }\end{array}$ & $\begin{array}{c}0.68 \\
(0.49,0.87)\end{array}$ & $\begin{array}{c}0.99 \\
(0.48,1.5)\end{array}$ & $\begin{array}{c}2 \cdot 0 \\
(1 \cdot 8,2 \cdot 2)\end{array}$ & $2 \cdot 5^{*}$ & $1 \cdot 78^{*}$ & $1 \cdot 85^{*}$ & $1 \cdot 16^{*}$ \\
\hline
\end{tabular}

* Insufficient quantities of fluid for duplicate assays.

The progesterone content of two pools of blastocyst fluid was measured and found to be 0.125 and $0.280 \mathrm{ng} / \mathrm{ml}$. This is insignificant compared to the progesterone levels of $>2 \mathrm{ng} /$ culture consistently found in the medium from cultured granulosa cells.

\section{Discussion}

These observations support the concept that there may be a gonadotrophin in the preimplantation rabbit blastocyst and confirm and extend the earlier observations of Haour \& Saxena (1974) and Fujimoto et al. (1975). The inability of Sundaram et al. (1975) to observe any activity in testis cells may have been due to the method of harvest, because freezing the entire blastocyst before separating the fluid may release proteolytic enzymes, or the gonadotrophin may be labile in the testis assay system. The latter explanation may also be the reason why Holt et al. (1976) failed to detect blastocyst fluid activity with an ovarian assay. Alternatively, the longer culture period used in the present studies may be better for demonstrating small amounts of a luteotrophic substance. The evidence derived from the radioreceptor assays for hCG activity in blastocyst fluid strengthens that from the granulosa cell cultures.

While these data do not prove that there is a discrete gonadotrophin secreted by the rabbit blastocyst before implantation, they are strongly indicative. The finding that the activity is nondialysable suggests that the molecular weight of the material may be $>10000$, and it thus resembles LH and hCG which have molecular weights of 30000 and 38000 , respectively. The alteration of progesterone secretion in the cultures by other blastocyst components, which are also non-dialysable, or which are bound to large molecules, cannot be ruled out.

The fact that we have demonstrated a biologically active hCG-like activity in rabbit blastocyst fluid gives added physiological significance to the concept of a preimplantation gonadotrophin which could start the rescue of the corpus luteum. Saxena, Hasan, Haour \& Schmidt-Gollwitzer (1974) have detected, with a radioreceptor assay, a rise in chorionic gonadotrophin in the blood of women before implantation and Wiley (1974) has demonstrated hCG-like activity in mouse morulae by a histoimmunoffuorescence technique. The observation of Dickmann (1976) that blastocysts secrete steroid hormones in early stages of implantation lends support for a role of an embryonic gonadotrophin which could act locally to stimulate this steroidogenesis.

Supported by Research Grants HD-08815 (CPC) from the Institute of Child Health and Human Development, from the World Health Organization and from the Lalor Foundation.

\section{References}

Channing, C.P. (1970) Effects of stage of the menstrual cycle and gonadotropins on luteinization of rhesus monkey granulosa cells in culture. Endocrinology 87, 156-164.

Channing, C.P. (1974) The use of granulosa cell cultures and suspensions as an assay system for measuring LH and CG. In Gonadotropins and Gonadal Function, pp. 185-198. Ed. N. R. Moudgal. Academic Press, New York.

Channing, C.P. \& Coudert, S.P. (1976) Contribution of granulosa cells and follicular fluid to ovarian estrogen secretion in the rhesus monkey in vivo. Endocrinology 98, 568-575.




hCG, asialo and hCG subunits upon luteinization of monkey granulosa cells. Endocrinology 93, 10351043.

Channing, C.P. \& Ledwitz-Rigby, F. (1975) Methods for assessing hormone-mediated differentiation of ovarian cells in culture and in short term incubations. In Methods in Enzymology, pp. 183-230. Eds J. G. Hardman \& B. W. O'Malley. Academic Press, New York.

Channing, C.P., Licht, P., PaPkoff, H. \& Donaldson, E. (1974) Comparative activities of mammalian, reptilian, and piscine gonadotropins in monkey granulosa cell cultures. Gen. comp. Endocr. 22, 737745.

Channing, C.P., Tsai, V. \& SaChs, D. (1976) Endocrine control of luteinization of porcine granulosa cells in chemically defined media: role of thyroxin and cortisol. Biol. Reprod. 15, 235-247.

DickmanN, Z. (1976) A new concept. Control of early pregnancy by steroid hormones originating in the preimplantation embryo. Vitams Horm. 36, 215-242.

Fuchs, A.R. \& Beling, C. (1974) Evidence for early ovarian recognition of blastocysts in rabbits. Endocrinology 95, 1054-1058.

Fujimoto, S., Euker, J., Riegel, G. \& Dukelow, W. (1975) On a substance crossreacting with luteinizing hormone in the preimplantation blastocyst fluid of the rabbit. Proc. Japan Acad. 51, 123-125.
Haour, F. \& Saxena, B.B. (1974) Detection of a gonadotropin in rabbit blastocyst before implantation. Science, N.Y. 185, 444-445.

Holt, J.A., Heise, W.F., Wilson, S.M. \& Keyes, P.L. (1976) Lack of gonadotropic activity in the rabbit blastocyst prior to implantation. Endocrinology 98, 904-909.

Hotchkiss, J., Atkinson, L. \& Knobil, E. (1971) Time course of serum estrogen and luteinizing hormone (LH) concentrations during the menstrual cycle of the rhesus monkey. Endocrinology 89, 177-183.

Sakai, C.N., Engel, B. \& Channing, C. (1977) Ability of an extract of pig corpus luteum to inhibit binding of ${ }^{125}$ I-labelled hCG to porcine granulosa cells. Proc. Soc. exp. Biol. Med. 155, 373-376.

Saxena, B., Hasan, S., Haour, F. \& Schmidt-GollWITZER, M. (1974) Radioreceptor assay of human chorionic gonadotropin detection of early pregnancy. Science, N. Y. 184, 793-795.

Sundaram, K., Connell, K. \& Passantino, T. (1975) Implication of absence of HCG-like gonadotrophin in the blastocyst for control of corpus luteum function in pregnant rabbit. Nature, Lond. 256, 739-741.

WiLEY, L.D. (1974) Presence of a gonadotropin on the surface of preimplanted mouse embryos. Nature, Lond. 252, 715-716.

Received 11 October 1977 